\title{
ASSESSING OIL SPILL RISK IN LOWER COOK INLET, ALASKA
}

\author{
ZHEN-GANG JI, CARYN SMITH \& WALTER R. JOHNSON \\ Bureau of Ocean Energy Management, USA
}

\begin{abstract}
The U.S. Federal Government offered for oil and gas leasing a portion of the U.S. Outer Continental Shelf (OCS) lands in Cook Inlet, Alaska (Lease Sale 244). Because oil spills may occur from activities associated with offshore oil and gas exploration, production, decommissioning, and transportation, the U.S. Department of the Interior Bureau of Ocean Energy Management conducts oil spill risk analysis (OSRA) to support National Environmental Policy Act analyses prior to conducting an oil and gas lease sale. The objective of OSRA is to estimate the probability of oil spill occurrence, the probability of oil spill contact, and the probability of oil spill occurrence and contact to sensitive offshore and onshore environmental resources and socioeconomic features from hypothetical oil spills accidentally occurring from OCS oil and gas-related activities. This paper presents the results of OSRA conducted for use in the Cook Inlet OCS Oil and Gas Lease Sale 244 Environmental Impact Statement. The OSRA model estimated oil spill trajectories using model-simulated hindcast fields of winds, sea ice movement and concentration, and surface ocean currents in the Cook Inlet, Shelikof Strait, and Gulf of Alaska. This paper also summarizes stochastic contact patterns and associated risks.
\end{abstract}

Keywords: oil spill, risk analysis, OSRA model, Cook Inlet.

\section{INTRODUCTION}

The U.S. Federal Government offered a portion of the U.S. Outer Continental Shelf (OCS) lands in Cook Inlet, Alaska, for oil and gas leasing (Lease Sale 244, Figs 1 and 2). Because oil spills may occur from activities associated with offshore oil and gas exploration, production, decommissioning, and transportation, the U.S. Department of the Interior (USDOI) Bureau of Ocean Energy Management (BOEM) conducts oil spill risk analysis (OSRA) to support National Environmental Policy Act (NEPA) analyses completed prior to conducting an oil and gas lease sale. This paper summarizes the OSRA data and results used in the Cook Inlet OCS Oil and Gas Lease Sale 244 Environmental Impact Statement (EIS) to estimate the probability of oil spill contact, the probability of oil spill occurrence, and the probability of oil spill occurrence and contact to sensitive offshore and onshore environmental resources and socioeconomic features from oil spills accidentally occurring from OCS oil and gas-related activities.

The occurrence of oil spills is fundamentally a matter of probability. There is no certainty regarding the amount of oil and gas that would be discovered and then produced, or that an oil spill would occur during the estimated life of a given lease sale. Furthermore, the winds, ocean currents, and sea ice that transport oil spills cannot be known for certain. A probabilistic event, such as an oil spill occurrence or oil spill contact to an environmental, social, or economic resource, cannot be predicted, but an estimate of its likelihood (probability) can be quantified.

\section{FRAMEWORK OF THE ANALYSIS}

Many factors are considered when producing an OSRA for a proposed lease sale. These include the study area, the area proposed for leasing (Proposed Action) and its alternatives, the estimated volume of oil and gas resources in the proposed leasing area, and the individual components of the OSRA model. 
The purpose of the Proposed Action and its alternatives is to offer for lease certain OCS blocks located within the federally owned portion of Cook Inlet that may contain economically recoverable oil and gas resources. As shown in Fig. 1, the study area for this analysis, which extends from $147^{\circ} \mathrm{W}$ to $160^{\circ} 15^{\prime} \mathrm{W}$ and $55^{\circ} 15^{\prime} \mathrm{N}$ to $61^{\circ} 15^{\prime} \mathrm{N}$, encompasses the geographic boundaries of the environmental, social, and economic resources evaluated in the OSRA model. The study area is enclosed by 16 offshore boundary segments and the Cook Inlet, Kodiak Island, Alaska Peninsula, and Gulf of Alaska coastline.

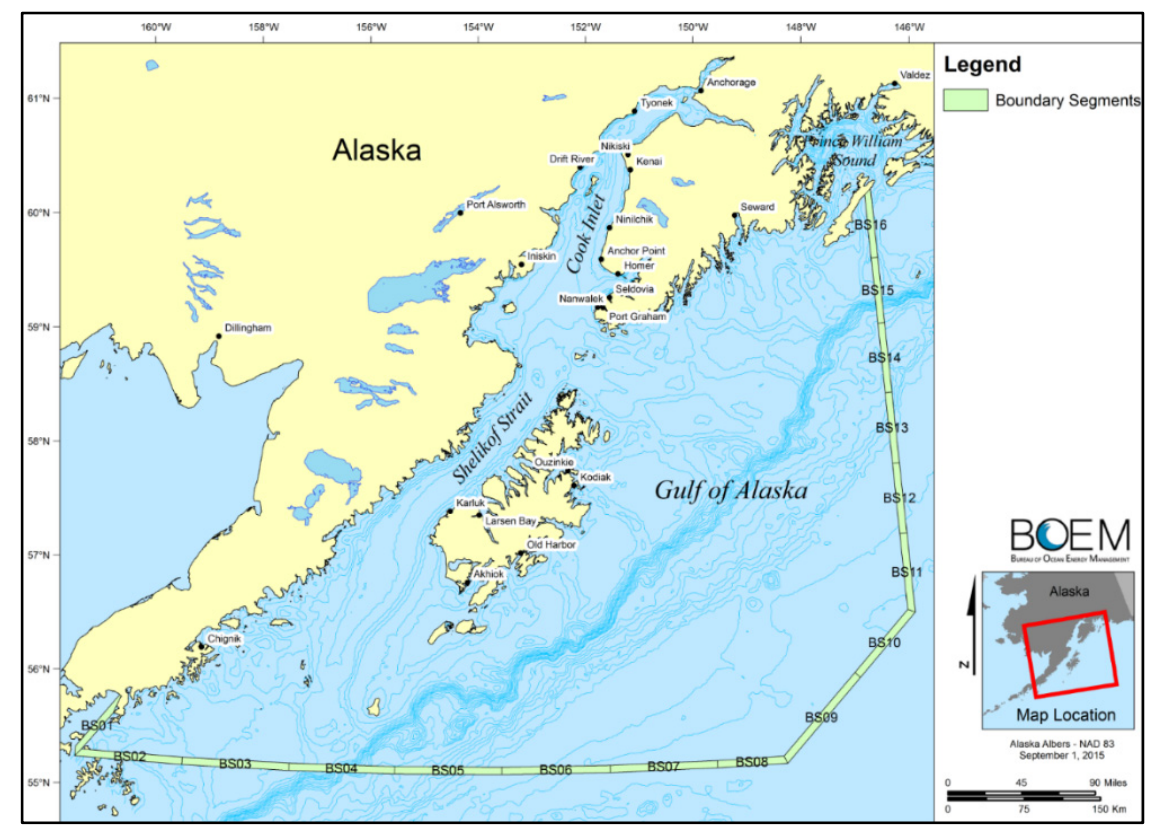

Figure 1: Model domain used in the oil spill trajectory analysis.

For the analysis, both benefits and risks are functions of the volume of oil and gas produced and are mutually dependent. For example, greater volumes of produced oil are associated with greater economic benefits, as well as greater risks. BOEM estimated that an undiscovered economic resource of approximately 0.215 billion barrels of oil (bbl) and 571 billion cubic feet of natural gas in two fields within the proposed Cook Inlet Lease Sale Area could be discovered and developed as a result of Lease Sale 244 [1].

The estimated life of all exploration, development, production, and decommissioning activities that result from the proposed Lease Sale 244 is 40 years. The exploration and development scenario is based on the assumption that the oil and gas produced in the proposed lease sale area would be transported to shore by pipelines and used within the State of Alaska [1]. No tankering of resources is estimated within the proposed lease sale area or to markets outside Alaska.

OSRA is conducted in three parts that correspond to different aspects of the overall problem: 1) the probability of large oil spill occurrence; 2) the trajectories of large oil spills from hypothetical spill locations to various resources; and 3) a combination of the first two analyses to estimate the overall oil spill risk of both spill occurrence and spill contact if oil development, production, and transportation occurs. 


\section{OIL SPILL RISK ANALYSIS}

This section details the three components of the OSRA for Lease Sale 244. This OSRA study focused on large spills. Large spills are those greater than or equal to $(\geq) 1,000 \mathrm{bbl}$, meaning that 1,000 bbl was the minimum threshold size for a large spill. A small spill (less than $[<]$ $1,000 \mathrm{bbl}$ ) would not be expected to persist on the water long enough for the model to follow its path in a trajectory analysis, but a large spill would.

This study used large OCS platform and pipeline spill occurrence rates from Anderson et al. [2]. BOEM multiplied the large OCS spill rate by the resource volume to estimate the mean number of spills. Smith et al. [3] described the details of this method. BOEM estimated a mean number of 0.19 pipeline spills and 0.05 platform (and well) spills could occur, for a total of 0.24 spills over the life of activities that may result from Lease Sale 244.

The probability of oil spills occurring assumes that spills occur independently of each other as a Poisson process. The Poisson distribution is a statistical distribution that is commonly used to model random events [3]. Using Poisson distribution, Table 1 shows the probability of one or more large spills occurring over the life of the development(s).

Table 1: Probability of one or more large spills occurring over the life of activities that may result from Lease Sale 244.

\begin{tabular}{|c|c|c|c|}
\hline & $\begin{array}{c}\text { Platform/well spills } \\
(\%)\end{array}$ & $\begin{array}{c}\text { Pipeline spills } \\
(\%)\end{array}$ & $\begin{array}{c}\text { Total }^{1} \\
(\%)\end{array}$ \\
\hline Lease Sale 244 & 5 & 17 & 22 \\
\hline
\end{tabular}

The OSRA model was designed to track the movements of hypothetical large oil spills and to estimate the probability of potential contacts to the environmental, social, and economic resources, which include environmental resource areas (ERAs), land segments (LSs), grouped land segments (GLSs), and boundary segments (BSs). ERAs represent offshore areas of social, economic, or biological resources or resource habitats, while LSs and GLSs represent onshore areas of social, economic, or biological resources or resource habitats. The OSRA model, originally developed by Smith et al. [3], has been enhanced by BOEM over the years [4]-[12].

The OSRA model estimated oil spill trajectories using model-simulated hindcast fields of winds, sea ice movement and concentration, and surface ocean currents in the Cook Inlet and Gulf of Alaska. BOEM used the results from a coupled ice-ocean general circulation model to simulate oil spill trajectories. The wind-driven and density-induced ocean-flow fields and the ice-motion and concentration fields were simulated using a state-of-the-art three-dimensional, coupled, ice-ocean hydrodynamic model based on the Regional Ocean Modeling System (ROMS) [13]. BOEM used the same Modern Era Retrospective Analysis for Research and Applications wind fields used by Danielson et al. [13]. The wind data were interpolated to the coupled ocean model grid at 3-hour intervals.

The OSRA model domain had a resolution of $245 \mathrm{~m}$ by $256 \mathrm{~m}$ and a total of 8 million grid cells (Fig. 1). It was chosen to be large enough to allow most hypothetical oil spill trajectories to develop without contacting the boundary segments through as long as 110 days. Although few hypothetical trajectories were likely to travel beyond the boundaries of the domain within 110 days after release (the maximum elapsed time considered), BOEM tracked and tabulated the few trajectories that contacted the open-ocean boundaries. If a spill were large enough to persist more than 110 days, these trajectories could contact land or other resource areas outside the domain. 
Hypothetical launch points are the locations where oil spill trajectories start. Hypothetical launch points were spaced at one per OCS lease block within the lease sale area, plus two additional launch points for pipelines leading to shore. Hypothetical launch points were spaced every $4.8 \mathrm{~km}$ in the east-west and north-south direction. At this resolution, there were 219 total launch points, grouped into the six larger launch areas and four pipelines representing the proposed area for Lease Sale 244 and potential associated infrastructure (Fig. 2).

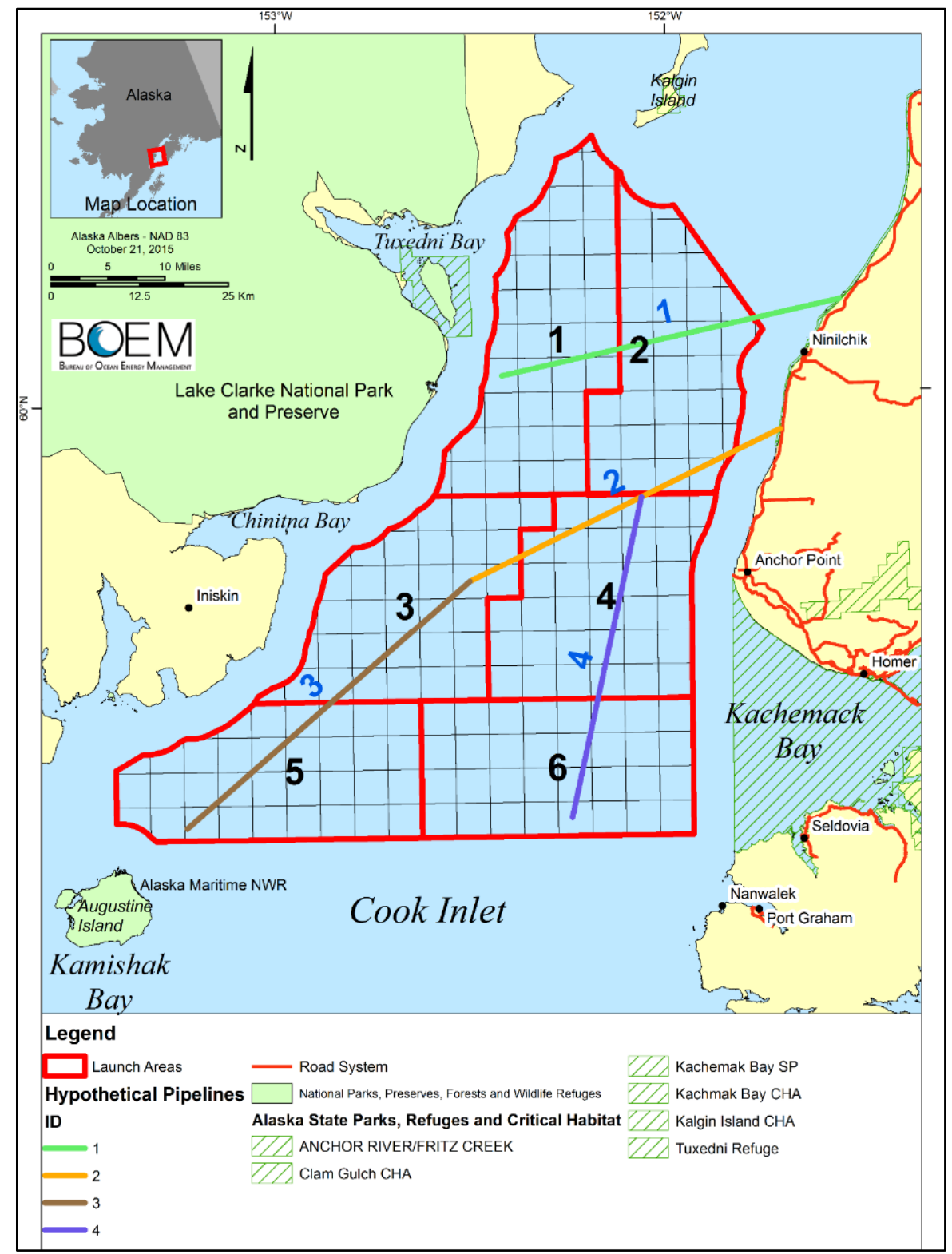

Figure 2: $\quad$ Proposed Lease Sale 244 area with hypothetical launch areas and pipelines used in the oil spill trajectory analysis. 
The pipelines were not meant to represent any real, planned, or proposed pipeline locations. They were distributed throughout the proposed lease sale area to evaluate differences in oil spill trajectories from different locations. If and when any commercial hydrocarbons are discovered, detailed development scenarios would be engineered, designed, reviewed, and evaluated by industry, BOEM, and other applicable regulatory agencies.

The trajectory-simulation portion of the OSRA model consists of many hypothetical oil spill trajectories that collectively represent the mean surface transport and the variability of the surface transport as a function of time and space [5]. The trajectories represent the Lagrangian motion that a particle on the surface might take under given wind, ice, and oceancurrent conditions. Hundreds of thousands of trajectories are simulated to give a statistical representation, over time and space, of possible transport under the range of wind, ice, and ocean-current conditions that exist in the OSRA study area.

There are factors not explicitly considered by the oil spill trajectory simulation that can affect the transport of spilled oil, as well as the dimensions, volume, and nature of the oil spill contacting environmental, social, or economic resources. These factors include possible clean-up operations, physical or biological weathering of oil spills, and the spreading and splitting of oil spills. For NEPA analyses, BOEM has chosen to take a more conservative analytical approach by presuming persistence of spilled oil over the selected time duration of the trajectories. These assumptions make the OSRA model's calculated probabilities conservative, as it does not take into account the weathering of oils and prevention and response measures that would be in place to prevent and reduce the potential effects and consequences of an accidental event. However, weathering and response are evaluated separately in the EIS without the use of OSRA.

The OSRA model launched a hypothetical oil spill trajectory from a hypothetical location, called a launch point, starting on day 1 in 1999, and it continuously launched the trajectory every day for a total of 10 years (1999-2009). A total of 3,600 trajectories were simulated from each of 219 launch points, for a total of 799,350 trajectories.

The trajectories were driven by the hourly wind and ice or current data from a coupled ocean model with 10 years (1999-2009) of simulation [13]. The OSRA model integrates the spill velocities (a linear superposition of surface ocean currents and empirical wind drift) by integrating velocity in time to produce the spill trajectories. The time step selected was 3 minutes to fully utilize the spatial resolution of the ocean current field and to achieve a stable set of trajectories. The velocity field was bi-linearly interpolated from the 1-hourly grid to get velocities at 3-minute intervals. Time steps smaller than 3 minutes were analysed and were found to not produce significant differences in the simulated trajectories after 110 model days, so the 3-minute time step was chosen for this analysis. The chosen number of trajectories was small enough to be computationally practical and large enough to reduce the random sampling error to an insignificant level.

Trajectories were constructed to produce an oil-transport vector. For cases where the ice concentration was below $80 \%$, each trajectory was constructed using vector addition of the ocean current field and $3.5 \%$ of the instantaneous wind field - a method based on work done by Huang and Monastero [14], Smith et al. [3], and Stolzenbach et al. [15]. For cases where the ice concentration was $80 \%$ or greater, the model ice velocity was used to transport the oil. Eqn (1) shows the components of motion simulated and used to describe the oil transport for each trajectory:

$$
U_{\text {oil }}=\left\{\begin{array}{c}
U_{\text {current }}+0.035 U_{\text {wind }} \text { if ice concentration }<80 \% \\
U_{\text {ice }} \text { if ice concentration } \geq 80 \%
\end{array},\right.
$$


where Uoil $=$ oil drift vector, Ucurrent $=$ current vector $($ when ice concentration was $<80 \%$ ), Uwind $=$ wind speed at $10 \mathrm{~m}$ above the sea surface, and Uice $=$ ice vector (when ice concentration was $\geq 80 \%$ ). The wind-drift factor was estimated to be 0.035 , with a variable drift angle ranging from $0^{\circ}-25^{\circ}$ clockwise. The drift angle was computed as a function of wind speed according to the equation in Samuels et al. [16].

The resource areas in this analysis (totalling 155 ERAs) represent concentrations of wildlife, habitat, subsistence-hunting areas, or subsurface habitats. Fig. 3 shows some of the ERAs. All of the onshore coastal resource locations were represented by one or more partitions of the coastline (LSs). The study area coastline was partitioned into 112 equidistant LSs of approximately 20-25 km in length. The LSs were further grouped into 52 larger geographic areas (GLSs) and were evaluated as unique environmental resources.

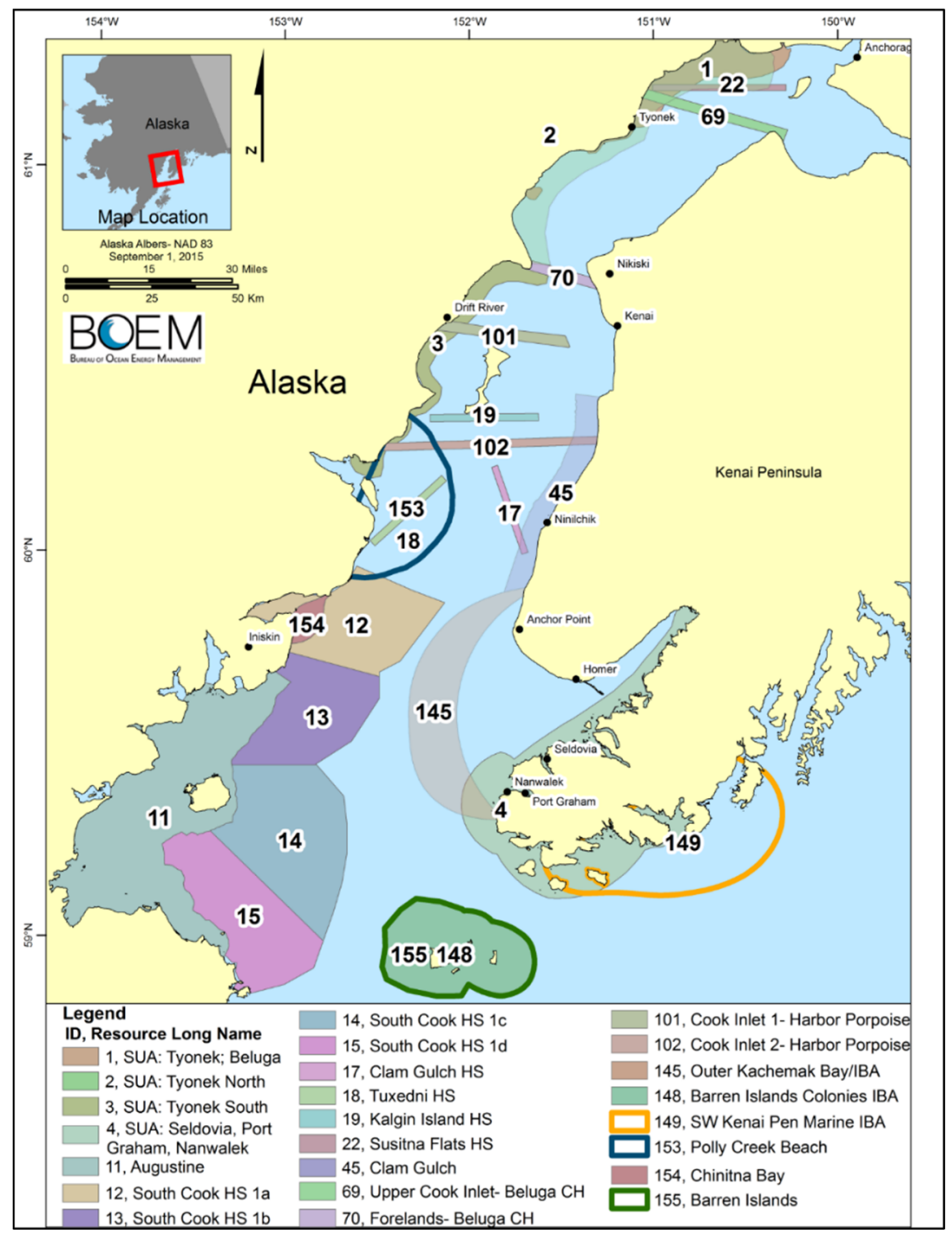

Figure 3: Environmental resource areas used in the oil spill trajectory analysis. 
The chance that a large oil spill will contact an environmental resource within a given time of travel from a certain location is termed a conditional probability. The condition is that a large spill is assumed to have occurred. Each trajectory was allowed to continue for as long as 110 days. However, if the hypothetical spill contacted a land segment sooner than 110 days after the start of the spill, the spill trajectory was terminated, and the contact was recorded. A contact to an ERA that is not a land segment did not stop the calculation of the trajectory.

The model estimated conditional probabilities of contact with environmental resources within $1,3,10,30$, and 110 days of travel time for each of the hypothetical spill sites to serve as input into the final estimation of the combined probabilities. Conditional probabilities are estimated by dividing the total number of contacts by the total number of oil spill trajectories initiated in the model from a given hypothetical spill location. At each successive time step, the OSRA model compares the location of the oil spill trajectories against the geographic boundaries of resources and their temporal vulnerability (the time in which the resource is there). The OSRA model then counts the number of "contacts", i.e., the number of trajectories contacting a resource during the time periods that the habitat is known to be used by the resource. The OSRA model combines the statistics for shoreline contacts by the trajectories to estimate the average probabilities of shoreline contact. For example, Table 2 shows the annual conditional probabilities (expressed as percent chance) that a large oil spill starting at a particular location will contact certain ERAs within 3 days.

Table 2: Annual conditional probabilities (expressed as percent chance) that a large oil spill starting at a particular location will contact an environmental resource area (ERA) within 3 days.

\begin{tabular}{|l|l|c|c|c|c|c|c|c|c|c|c|}
\hline ID & Environmental resource area name & $\mathbf{L A}$ & $\mathbf{L A}$ & $\mathbf{L A}$ & $\mathbf{L A}$ & $\mathbf{L A}$ & $\mathbf{L A}$ & $\mathbf{P L}$ & $\mathbf{P L}$ & $\mathbf{P L}$ & $\mathbf{P L}$ \\
\hline $\mathbf{0}$ & Land & 55 & 36 & 39 & 25 & 38 & 22 & 37 & 29 & 37 & 23 \\
\hline $\mathbf{2}$ & SUA: Tyonek North & 1 & - & - & - & - & - & - & - & - & - \\
\hline $\mathbf{3}$ & SUA: Tyonek South & 17 & 5 & - & - & - & - & 4 & 1 & - & - \\
\hline $\mathbf{4}$ & $\begin{array}{l}\text { SUA: Seldovia, Port Graham, } \\
\text { Nanwalek }\end{array}$ & 1 & 1 & 3 & 9 & 2 & 21 & 1 & 3 & 2 & 14 \\
\hline $\mathbf{1 1}$ & Augustine & 12 & 9 & 38 & 16 & 63 & 18 & 11 & 12 & 49 & 14 \\
\hline $\mathbf{1 2}$ & South Cook HS 1a & 59 & 56 & 83 & 63 & 5 & 27 & 66 & 61 & 43 & 46 \\
\hline $\mathbf{1 3}$ & South Cook HS 1b & 35 & 30 & 85 & 44 & 86 & 41 & 37 & 35 & 96 & 38 \\
\hline $\mathbf{1 4}$ & South Cook HS 1c & 11 & 7 & 35 & 15 & 59 & 24 & 10 & 9 & 54 & 16 \\
\hline $\mathbf{1 5}$ & South Cook HS 1d & 2 & 1 & 12 & 3 & 27 & 8 & 2 & 2 & 22 & 4 \\
\hline $\mathbf{1 6}$ & Inner Kachemak Bay & - & - & - & 3 & - & 3 & - & 1 & - & 3 \\
\hline $\mathbf{1 7}$ & Clam Gulch HS & 2 & 47 & - & 9 & - & 1 & 33 & 36 & - & 6 \\
\hline $\mathbf{1 8}$ & Tuxedni HS & 35 & 24 & - & 2 & - & - & 31 & 8 & - & 2 \\
\hline $\mathbf{1 9}$ & Kalgin Island HS & 16 & 14 & - & - & - & - & 6 & 3 & - & - \\
\hline $\mathbf{2 0}$ & Redoubt Bay HS & 8 & 2 & - & - & - & - & 1 & - & - & - \\
\hline $\mathbf{2 1}$ & Trading Bay HS & 1 & - & - & - & - & - & - & - & - & - \\
\hline $\mathbf{2 3}$ & Barren Isl. Pinn & - & - & 2 & 1 & 3 & 5 & - & - & 3 & 3 \\
\hline $\mathbf{2 4}$ & Shelikof MM 2 & - & - & - & - & 3 & - & - & - & 2 & - \\
\hline $\mathbf{3 7}$ & Port Chatham Pinniped & - & - & - & - & - & 1 & - & - & - & 1 \\
\hline $\mathbf{4 5}$ & Clam Gulch & 1 & 15 & - & 8 & - & 2 & 19 & 39 & - & 6 \\
\hline
\end{tabular}


Correspondingly, Table 3 presents the combined probabilities (expressed as percent chance) of the same ERAs. Ji et al. [10] provides detailed results, including about 70 tables and 20 figures.

Table 3: Combined probabilities (expressed as percent chance) over the assumed life of the Lease Sale 244 area of one or more spills $\geq 1,000 \mathrm{bbl}$, and the estimated number of spills (mean), occurring and contacting certain environmental areas.

\begin{tabular}{|l|l|c|c|c|c|c|c|c|c|}
\hline \multirow{2}{*}{$\begin{array}{l}\text { ERA } \\
\text { ID }\end{array}$} & \multirow{2}{*}{ Environmental resource area name } & \multicolumn{2}{|c|}{1 day } & \multicolumn{2}{|c|}{3 days } & \multicolumn{2}{|c|}{10 days } & \multicolumn{2}{|c|}{30 days } \\
\cline { 3 - 10 } & & $\%$ & mean & $\%$ & mean & $\%$ & mean & $\%$ & mean \\
\hline 0 & Land & 2 & 0.02 & 9 & 0.09 & 18 & 0.19 & 21 & 0.23 \\
\hline 3 & SUA: Tyonek South & 1 & 0.01 & 1 & 0.01 & 2 & 0.02 & 2 & 0.02 \\
\hline 4 & $\begin{array}{l}\text { SUA: Seldovia, Port Graham, } \\
\text { Nanwalek }\end{array}$ & - & 0.00 & 1 & 0.01 & 2 & 0.02 & 3 & 0.03 \\
\hline 5 & SUA: Port Lions & - & 0.00 & - & 0.00 & 1 & 0.01 & 2 & 0.02 \\
\hline 6 & SUA: Ouzinke & - & 0.00 & - & 0.00 & 1 & 0.01 & 1 & 0.01 \\
\hline 11 & Augustine & 1 & 0.01 & 4 & 0.04 & 7 & 0.08 & 8 & 0.08 \\
\hline 12 & South Cook HS 1a & 9 & 0.09 & 13 & 0.14 & 14 & 0.16 & 14 & 0.16 \\
\hline 13 & South Cook HS 1b & 4 & 0.04 & 9 & 0.10 & 12 & 0.13 & 12 & 0.13 \\
\hline 14 & South Cook HS 1c & 1 & 0.01 & 3 & 0.03 & 7 & 0.08 & 8 & 0.08 \\
\hline 15 & South Cook HS 1d & - & 0.00 & 1 & 0.01 & 5 & 0.05 & 5 & 0.06 \\
\hline 16 & Inner Kachemak Bay & - & 0.00 & - & 0.00 & - & 0.00 & 1 & 0.01 \\
\hline 17 & Clam Gulch HS & 5 & 0.05 & 6 & 0.06 & 6 & 0.06 & 6 & 0.06 \\
\hline 18 & Tuxedni HS & 3 & 0.03 & 4 & 0.04 & 5 & 0.05 & 5 & 0.05 \\
\hline 19 & Kalgin Island HS & 2 & 0.02 & 2 & 0.02 & 3 & 0.03 & 3 & 0.03 \\
\hline 20 & Redoubt Bay HS & - & 0.00 & 1 & 0.01 & 1 & 0.01 & 1 & 0.01 \\
\hline 23 & Barren Isl. Pinniped & - & 0.00 & - & 0.00 & 1 & 0.02 & 2 & 0.02 \\
\hline 24 & Shelikof MM 2 & - & 0.00 & - & 0.00 & 2 & 0.02 & 3 & 0.03 \\
\hline 25 & Shelikof MM 3 & - & 0.00 & - & 0.00 & 1 & 0.01 & 1 & 0.01 \\
\hline 26 & Shelikof MM 4 & - & 0.00 & - & 0.00 & - & 0.00 & 1 & 0.01 \\
\hline 37 & Port Chatham Pinniped & - & 0.00 & - & 0.00 & - & 0.00 & 1 & 0.01 \\
\hline 45 & Clam Gulch & 1 & 0.01 & 2 & 0.02 & 3 & 0.03 & 3 & 0.03 \\
\hline
\end{tabular}

\section{RESULTS AND DISCUSSION}

The OSRA conditional probability results are discussed in terms of the chance of contact during intervals of 3,10, and 30 days. The primary differences in the magnitude of contact between hypothetical spill locations are geographic in the perspective of east to west and northern lower Cook Inlet versus southern lower Cook Inlet and Shelikof Strait. The LSs with the highest chance of contact from all launch areas are generally along the western shores of lower Cook Inlet in Kamishak Bay (Fig. 2) and Shelikof Strait (Fig. 1). Contacts to the western shorelines are greater in magnitude and length of coastline contacted was longer for launch areas located on the western side of Cook Inlet. Launch areas in southern Cook Inlet tend to produce patterns of contacts that show spills overall move more southward in the inlet. For a particular launch area, contacts to the south are farther away and higher in magnitude than contacts to the north. This trend reflects the predominate flow in the inlet and 
strait to the south. The pipelines generally have balanced east and west contacts. Winter contacts are generally slightly higher in magnitude than summer contacts for the same launch area or pipeline.

Three days: Generally, the highest chances of contacts to ERAs, LSs, and GLSs within 3 days occurred directly adjacent to the launch areas or pipelines.

Ten days: Generally, a large portion of the trajectories contacted shoreline within 10 days due to the enclosed nature of the shoreline of lower Cook Inlet and upper Shelikof Strait. In many cases, there was little difference between the 10-day and 30-day estimated chances of contact. This was because the study area was restricted within Cook Inlet and Shelikof Strait, and long travel times for oil spill trajectories were not observed.

Thirty days: The chance of contacts within 30 days generally increased only slightly, if at all, from 10 days. Some ERAs, located primarily in the lower Shelikof Strait and the northeastern side of Kodiak (farther from the launch areas), had chances of contact ranging from $1 \%-5 \%$. The majority of ERAs that were distant from the proposed lease sale area had a $<0.5 \%$ chance of contact.

Resource locations closest to the proposed lease sale area have the highest chance of occurrence and contact. As the trajectory travel time increases, more of the identified environmental resources and shoreline segments have meaningful probabilities of occurrence and contact $(>0.5 \%)$. The longer transit times (up to 30 days) enable more hypothetical spills to reach environmental resources and shorelines from more distant spill locations. With increased travel time, the complex patterns of wind and ocean currents produce multiple opportunities for a trajectory to contact any given environmental resource or shoreline segment.

Within 30 days, the onshore ERA has the highest combined probability (21\%). Except for the onshore ERA, the combined probability for individual ERAs was $14 \%$ or less. Sixty-two percent of the ERAs identified within the OSRA study area had a $<0.5 \%$ combined probability. Those ERAs with a 5\%-14\% combined probability were within or adjacent to the proposed lease sale area from southern Kalgin Island to northern Shelikof Strait, with the highest combined probabilities along western Cook Inlet. ERAs with a 1\%-4\% combined probability were farther from the proposed lease sale area, ranging from the Forelands in central Cook Inlet to southern Shelikof Strait and to the eastern Gulf of Alaska near the entrance to Cook Inlet [10].

Cook Inlet Oil and Gas Lease Sale 244 occurred on June 21, 2017. For more information, visit https://www.boem.gov/about-boem/cook-inlet-oil-and-gas-lease-sale-244.

\section{ACKNOWLEDGEMENT}

The authors would like to thank Paulina Chen for editing the manuscript.

\section{REFERENCES}

[1] Bureau of Ocean Energy Management (BOEM), Cook Inlet planning area oil and gas lease sale 244 in the Cook Inlet, Alaska. Final environmental impact statement, OCS EIS/EA BOEM 2016069, U.S. Department of the Interior, BOEM: Anchorage, AK, 2016.

[2] Anderson, C.M., Mayes, M. \& LaBelle, R., Update of occurrence rates for offshore oil spills, OCS report BOEM/BSEE 2012-069, U.S. Department of the Interior, BOEM and Bureau of Safety and Environmental Enforcement: Herndon, VA, 2012.

[3] Smith, R.A., Slack, J.R., Wyant, T. \& Lanfear, K.J., The oil spill risk analysis model of the U.S. U.S. Geological Survey professional paper 1227, U.S. Department of the Interior, U.S. Geological Survey: Reston, VA, 1982. 
[4] Ji, Z.-G., Use of physical sciences in support of environmental management. Environmental Management, 34(2), pp. 159-169, 2004.

[5] Ji, Z.-G., Hydrodynamics and Water Quality: Modeling Rivers, Lakes, and Estuaries. 2nd ed., John Wiley \& Sons, Inc.: Hoboken, NJ, 2017.

[6] Ji, Z.-G., Johnson, W.R. \& Li, Z., Oil spill risk analysis model and its application to the deepwater horizon oil spill using historical current and wind data. Monitoring and Modeling the Deepwater Horizon Oil Spill: A Record-Breaking Enterprise, eds Y. Liu, A. MacFadyen, Z.-G. Ji \& R.H. Weisberg, American Geophysical Union: Washington, D.C., pp. 227-236, 2011.

[7] Ji, Z.-G., Johnson, W.R. \& Marshall, C., Deepwater oil-spill modeling for assessing environmental impacts. Coastal Environment V: Incorporating Oil Spill Studies, eds C.A. Brebbia, J.M. Saval, L. Perez, G. Andion \& Y. Villacampa Esteve, WIT Press: UK, pp. 349-358, 2004.

[8] Ji, Z.-G., Johnson, W.R., Marshall, C.F., Rainey, G.B. \& Lear, E.M., Oil-Spill Risk Analysis: Gulf of Mexico Outer Continental Shelf(OCS) Lease sales, Central Planning Area and Western Planning Area, 2003-2007, and Gulfwide OCS Program, 20032042. OCS Report 2002-2032, U.S. Department of the Interior, Minerals Management Service: Herndon, VA, 2002.

[9] Ji, Z.-G., Johnson, W.R., Price, J.M. \& Marshall, C.F., Oil-Spill Risk Analysis for assessing environmental impacts. International Oil Spill Conference Proceedings, American Petroleum Institute: Washington, D.C., pp. 1125-1129, 2003.

[10] Ji, Z.-G., Smith, C. \& Johnson, W.R., Oil-Spill Risk Analysis: Cook Inlet Planning Area, OCS Lease Sale 244. OCS report 2016-032, U.S. Department of the Interior, BOEM: Sterling, VA, 2016.

[11] Price, J.M., Johnson, W.R., Ji, Z.-G., Marshall, C.F. \& Rainey, G.B., Sensitivity testing for improved efficiency of a statistical oil-spill risk analysis model. Environmental Modelling \& Software, 19(7), pp. 671-679, 2004.

[12] Price, J.M., Johnson, W.R., Marshall, C.F., Ji, Z.-G. \& Rainey, G.B., Overview of the Oil Spill Risk Analysis (OSRA) Model for environmental impact assessment. Spill Science and Technology Bulletin, 8(5-6), pp. 529-533, 2003.

[13] Danielson, S., Hedstrom, K. \& Curchitser, E., Cook Inlet circulation model calculations. Final report, BOEM OCS Study 2015-050, U.S. Department of the Interior, BOEM: Anchorage, AK, 2016.

[14] Huang, J.C. \& Monastero, F.M. (Raytheon Ocean Systems Co.), Review of the Stateof-the-Art of Oil Spill Simulation Models. American Petroleum Institute: East Providence, RI, 1982.

[15] Stolzenbach, K.D., Madsen, O.S., Adams, E.E., Pollack, A.M. \& Cooper, C.K., A review and evaluation of basic techniques for predicting the behavior of surface oil slicks. Ralph M. Parsons Laboratories Report No. 222, Massachusetts Institute of Technology: Cambridge, MA, 1977.

[16] Samuels, W.B., Huang, N.E. \& Amstutz, E.D., An oil spill trajectory analysis model with a variable wind deflection angle. Ocean Engineering, 9(4), pp. 347-360, 1982. 